Available online at GSC Online Press Directory

GSC Biological and Pharmaceutical Sciences

e-ISSN: 2581-3250, CODEN (USA): GBPSC2

Journal homepage: https://www.gsconlinepress.com/journals/gscbps

(RESEARCH ARTICLE)

\title{
Sensory properties, physical and microbiological studies of pumpkin seed (Cucurbita реро) blended cakes
}

\author{
Christian Chukwuemeka Ike ${ }^{1, *}$, Peace Chika Emeka-Ike ${ }^{2}$ and Happiness Odinakachi Ogwuegbu ${ }^{3}$ \\ ${ }^{1}$ Department of Biological Sciences (Microbiology Programme), College of Basic and Applied Sciences, Rhema University, \\ Nigeria, P.M.B. 7021 Aba, Abia State. \\ ${ }^{2}$ Department of Food Science and Technology, Imo State University, Owerri, P.M.B. 2000 Owerri, Imo State, Nigeria. \\ ${ }_{3}^{3}$ Department of Microbiology, Abia State University Uturu, P.M.B. 2000 Uturu, Abia State, Nigeria.
}

Publication history: Received on 13 July 2020; revised on 06 September 2020; accepted on 09 September 2020

Article DOI: https://doi.org/10.30574/gscbps.2020.12.3.0224

\begin{abstract}
Sensory properties, physical and microbiological studies of pumpkin seed (Cucurbita pepo) blended cakes were evaluated using standard analytical and microbiological methods. Peroxide values of blended cakes were also evaluated. CF2 blend (20\% pumpkin) had the highest mean sensory scores for all sensory parameters and was found to be higher than control (WF1) with overall acceptability of 8.25 $\pm 0.58 / 5.36 \pm 0.61$ at day $1 /$ day 4 and $8.40 \pm 0.64 / 8.20 \pm 0.96$ at day $1 /$ day 4 under ambient and refrigeration conditions respectively. The weight ( $\mathrm{g}$ ) of the blended cakes ranged from $34.95 \pm 0.27$ to $39.16 \pm 0.02$. CF6 (60\% pumpkin) cake recorded the highest weight of $39.16 \pm 0.02 \mathrm{~g}$ while wheat flour (WF1) cake recorded the least weight of $34.95 \pm 0.27 \mathrm{~g}$. The volume $\left(\mathrm{cm}^{3}\right)$ and specific volume $\left(\mathrm{cm}^{3} / \mathrm{g}\right)$ of blended cakes ranged from $91.89 \pm 0.17$ to $96.61 \pm 0.07$ and $2.35 \pm 0.04$ to $2.75 \pm 0.14$ respectively. Peroxide values of blended cakes ranged from $4.23 \pm 0.03 \mathrm{meq} / \mathrm{kg}$ to $4.92 \pm 0.04 \mathrm{meq} / \mathrm{kg}$. CF2 cake had the highest peroxide value of $4.92 \pm 0.04 \mathrm{meq} / \mathrm{kg}$ among the blends, although lower than that of WF1 cake while CF6 cake had the least peroxide value of $4.23 \pm 0.03$ $\mathrm{meq} / \mathrm{kg}$. Bacterial and fungal counts (CFU/g) of baked cakes ranged from $1.40 \times 10^{2} \pm 0.58$ to $2.99 \times 10^{3} \pm 1.00$ and $2.50 \times 10^{1} \pm 1.00$ to $2.40 \times 10^{2} \pm 2.08$ respectively. WF1 cake recorded the highest bacterial and fungal counts (CFU/g), while CF6 recorded the least bacterial and fungal counts (CFU/g) for both storage days under ambient and refrigeration conditions. From the results obtained, 20\% supplementation of pumpkin seed flour into wheat flour (CF2) produced cakes with the most acceptable sensory, physical and microbiological qualities, when compared with control and other levels of blends. Therefore, there is need for inclusion of pumpkin seed flour (PSF) into wheat flour (WF1) in order to enhance the shelf life stability, nutritional properties, quality and acceptability potentials of baked cakes.
\end{abstract}

Keywords: Pumpkin (Cucurbita pepo) seed; Sensory evaluation; Physical properties; Peroxide value; Microbiological study.

\section{Introduction}

Pumpkin belongs to the family Cucurbitaceae. It is a plant that has been traditionally used as a medicine in developing countries and obtained revival of use in the United States and Europe [1]. Pumpkin has gained extensive attention in current times due to the good nutritional composition and health shielding values of its seeds [2]. Pumpkin seeds are loaded with nutrients and medicinal properties, due to which the seeds are used for remedial purposes all over the world. Pumpkin seeds are often eaten as snack after roasting and salting in Arab countries [3].

\footnotetext{
${ }^{*}$ Corresponding author: Ike Christian Chukwuemeka

Department of Biological Sciences (Microbiology Programme), College of Basic and Applied Sciences, Rhema University, Nigeria, P.M.B. 7021 Aba, Abia State.
} 
Proteins are commonly employed as food ingredients on the basis of their importance in human diets. The best proteins belong to animal sources, since they are nutritionally better. However the high cost of animal protein makes vegetable protein the main dietary component for most of the world's population. The use of plant protein in the formulation of new food products or in conventional foods has been the focus of most research in recent years. One gram of pumpkin seed protein contains as much tryptophan as a full glass of milk. The main storage proteins are salt soluble globulins accompanied by glutelins and lesser amounts of albumins and prolamins [4].

Pumpkin is still not widely used in the food industry, but is consumed in homes worldwide in dishes such as pumpkin bread, soup, pie, etc[5]. The hulled or semi-hulled seeds of pumpkins could be roasted and eaten as snack. The seed can be prepared for eating by first separating them from the pumpkin flesh, then coating them in a generally salty sauce after which the seeds are distributed upon a baking sheet, and then cooked in an oven at $a$ relatively low temperature for a long period of time [6; 7].

Pumpkin (Cucurbita pepo) has received attention in recent years because of the nutritional and health protective values of the seeds [8]. The seed is an excellent source of protein which also has pharmacological activities such as antidiabetics [9], anti-fungi [10], antibacterial and anti-inflammation activities [1]. Research has shown that the seeds have antioxidant effects [11]. Proteins may contribute to food flavour through one of the following: bound molecules, absorption, breakdown products and chemical reactions. In addition to the good nutritional and health benefits of Cucurbita seeds, they are cheap and are widely distributed [12].

The serious consequences of malnutrition particularly among infants and children form a primary roadblock to social and economic development. Recently, more attention has been focused on the utilization of underutilized agricultural products. Obviously such utilization would contribute to maximizing available resources and results in the production of various new food products. Preservation of vegetable and fruits is an excellent way to curb post- harvest losses which are major challenges in sub-Sahara African countries $[13 ; 14]$.

Processing methods are employed mostly to preserve and improve the organoleptic properties of foods, microbial quality and equally to enhance shelf life [15]. The rich nutrition base of pumpkin can be tapped to improve the nutritional quality of baked products, soup and sauces [13]. A pleasing green colour and nutty taste of pumpkin seed flour makes it feasible to be used in developing new food products such as in fortified wheat flour to produce bakery products like pastries with unique and nutty taste [16]. The use of white flour from processed whole wheat grain leads to drastic reduction in nutritional density and fibre content [17]. These days, awareness by consumers on the need to eat high quality and healthy foods known as functional foods that contains ingredients providing additional healthy benefits beyond the basic nutritional requirements, is increasing [18]. Hence, this work is aimed at evaluating the sensory properties, physical and microbiological studies of pumpkin seed (Cucurbita pepo) blended cakes.

\section{Material and methods}

\subsection{Sensory evaluation}

Twenty five (25) samples of the cake were prepared using wheat flour (WF1) as control, and composite samples prepared by supplementing wheat flour with pumpkin seed flour at different percentages (20\%, 40\%, 50\% and 60\%) representing CF2, CF4, CF5 and CF6 respectively. Sensory evaluation test was done on the first day of production and the fourth day during storage at both ambient and refrigeration conditions. The consumer acceptance of five different samples of cakes was evaluated by twenty five judges comprising untrained candidates. The sensory evaluation test was conducted in the air-conditioned laboratory, which provided a quiet and comfortable environment. The cakes were served on white disposable plastic trays and packaged-potable water was provided for mouth rinsing. Samples were coded with different symbols and the sample order was randomized. The judges were asked to evaluate the colour, taste, flavor, texture and overall acceptability of the cakes using a 9-point hedonic scale.

\subsection{Physical characteristics of the cakes}

The physical characteristics of the enriched cakes were measured using the method outlined by [19] and reported by [20] for fluted pumpkin cookies and adopted by [21].

\subsection{Peroxide value determination}

The method described by [22] was adopted in the determination of peroxide value of pumpkin (Cucurbita pepo) seed composite flours. 


\subsection{Microbiological analyses of baked cakes}

Baked cakes from composite flours were analyzed for bacterial and fungal counts using spread plate method as described by [23]. Ten fold serial dilutions of flour samples were done using sterile peptone water as diluent. One gramme $(1 \mathrm{~g})$ each of mashed sample was aseptically transferred into a sterile test tube containing nine milliliter $(9 \mathrm{~mL})$ of sterile peptone water, stirred with sterile glass rod and was shaken vigorously to ensure adequate disengagement of microorganisms to obtain $10^{-1}$ dilution. Serial dilutions of the homogenates were continued and made step-wisely till the fifth (5th) tube, to obtain dilutions of $10^{-2}$ to $10^{-5}$. Spread plate techniques of [23] were used to enumerate bacteria and fungi in the samples and each dilution was plated in replicates using plate count agar for mean bacterial count, and fortified sabouraud dextrose agar (SDA) for mean fungal count. The plates were incubated at $35 \pm 2{ }^{\circ} \mathrm{C}$ for 72 hours for mean bacterial counts and $25 \pm 2{ }^{\circ} \mathrm{C}$ for 120 hours for mean fungal counts. Pure bacterial isolates were identified using cultural, morphological and biochemical characterization. Identification of the bacteria to genera level was based on the schemes of [24]. The purified fungal isolates were identified on the basis of macroscopic and microscopic characteristics by slide culture technique and lactophenol staining. The scheme of [25] was used for the identification.

\subsection{Statistical analyses}

All obtained data in this study were analyzed using analysis of variance (ANOVA). Descriptive statistics in form of mean, standard deviation and Duncan post hoc were also used to assess the data, and analyses were done using SPSS version 20 (Statistical Product and Service Solutions).

\section{Results}

\subsection{Sensory evaluation}

The mean scores of sensory evaluation of cakes by semi-trained panelist using nine-point hedonic rating scale for day 1 and day 4, under ambient and refrigeration conditions are presented in Table 1. The highest scores for all sensory parameters was obtained by CF2 blend and was found to be higher than control (WF1) with overall acceptability of $8.25 \pm 0.58 / 5.36 \pm 0.61$ at day $1 /$ day 4 and $8.40 \pm 0.64 / 8.20 \pm 0.96$ at day $1 /$ day 4 under ambient and refrigeration conditions respectively. The other three blends such as CF4, CF5 and CF6 had lower overall acceptability scores of $6.29 \pm 1.41 / 3.48 \pm 1.08 \& 6.52 \pm 0.82 / 6.16 \pm 1.34,5.22 \pm 1.19 / 2.40 \pm 1.38 \& 5.40 \pm 1.32 / 5.20 \pm 0.82$ and $4.96 \pm 1.72$ / $2.00 \pm 1.49 \& 4.92 \pm 1.68 / 4.56 \pm 1.04$ when compared with control (WF1) with $7.11 \pm 0.51 / 4.24 \pm 0.60 \& 7.24 \pm 0.59 /$ $6.56 \pm 1.00$ at day $1 /$ day 4 under ambient and refrigeration conditions respectively.

\subsection{Physical properties}

The physical properties of baked cakes are shown in Table 2. The weight (g) of the cakes from the blends ranged from $34.95 \pm 0.27$ to $39.16 \pm 0.02$. CF6 cake recorded the highest weight of $39.16 \pm 0.02 \mathrm{~g}$ while WF1 cake recorded the least weight of $34.95 \pm 0.27 \mathrm{~g}$. The volume $\left(\mathrm{cm}^{3}\right)$ and specific volume $\left(\mathrm{cm}^{3} / \mathrm{g}\right)$ of cakes from blends ranged from $91.89 \pm 0.17$ to $96.61 \pm 0.07$ and $2.35 \pm 0.04$ to $2.75 \pm 0.14$ respectively. CF2 cake recorded the highest volume and specific volume of $96.61 \pm 0.07 \mathrm{~cm}^{3}$ and $2.75 \pm 0.14 \mathrm{~cm}^{3} / \mathrm{g}$, while CF6 cake recorded the least volume and specific volume of $91.89 \pm 0.17 \mathrm{~cm}^{3}$ and $2.35 \pm 0.04 \mathrm{~cm}^{3} / \mathrm{g}$ respectively. Values obtained when compared were statistically significant $(\mathrm{p}<0.05)$.

\subsection{Peroxide value}

The results of peroxide values of blended cakes are presented in Table 3. Peroxide values of blended cakes ranged from $4.23 \pm 0.03 \mathrm{meq} / \mathrm{kg}$ to $4.92 \pm 0.04 \mathrm{meq} / \mathrm{kg}$. CF2 cake had the highest peroxide value of $4.92 \pm 0.04 \mathrm{meq} / \mathrm{kg}$ among the blends, although lower than that of WF1 cake while CF6 cake had the least peroxide value of $4.23 \pm 0.03 \mathrm{meq} / \mathrm{kg}$ (Table $3)$. All values obtained were statistically significant $(\mathrm{p}<0.05)$. 
Table 1 Sensory scores of baked cakes for the different storage days and conditions.

\begin{tabular}{|c|c|c|c|c|c|c|c|c|c|c|c|c|}
\hline \multirow[t]{2}{*}{ Samples } & \multicolumn{2}{|c|}{ Appearance } & \multicolumn{2}{|l|}{ Colour } & \multicolumn{2}{|c|}{ Taste } & \multicolumn{2}{|c|}{ Texture } & \multicolumn{2}{|c|}{ Flavour } & \multicolumn{2}{|c|}{$\begin{array}{l}\text { Overall } \\
\text { Acceptability }\end{array}$} \\
\hline & Day 1 & Day 4 & Day 1 & Day 4 & Day 1 & Day 4 & Day 1 & Day 4 & Day 1 & Day 4 & Day 1 & Day 4 \\
\hline \multicolumn{13}{|c|}{ Under Ambient } \\
\hline WF1 & $7.16 \pm 0.80^{\mathrm{a}}$ & $4.02 \pm 0.15^{\mathrm{ab}}$ & $6.76 \pm 1.09 \mathrm{~b}$ & $3.68 \pm 1.03^{b}$ & $6.44 \pm 1.48^{b}$ & $3.52 \pm 1.23^{b}$ & $6.60 \pm 0.76^{b}$ & $3.56 \pm 0.43^{b}$ & $6.84 \pm 0.90^{\mathrm{b}}$ & $3.84 \pm 0.94 \mathrm{~b}$ & $7.11 \pm 0.51^{b}$ & $4.24 \pm 0.60^{b}$ \\
\hline CF2 & $7.84 \pm 0.90^{\mathrm{a}}$ & $4.76 \pm 1.28^{\mathrm{a}}$ & $8.01 \pm 0.15^{\mathrm{a}}$ & $5.20 \pm 1.12^{\mathrm{a}}$ & $8.24 \pm 0.23^{a}$ & $5.01 \pm 0.33^{\mathrm{a}}$ & $7.88 \pm 0.60^{a}$ & $4.33 \pm 0.14^{\mathrm{a}}$ & $7.92 \pm 0.95^{\mathrm{a}}$ & $4.97 \pm 0.83^{\mathrm{a}}$ & $8.25 \pm 0.58^{a}$ & $5.36 \pm 0.61^{\mathrm{a}}$ \\
\hline CF4 & $6.24 \pm 1.05^{b}$ & $3.24 \pm 1.05^{c}$ & $6.16 \pm 1.75^{b c}$ & $3.34 \pm 1.73^{b c}$ & $5.76 \pm 1.36^{\mathrm{b}}$ & $2.73 \pm 1.34^{b}$ & $6.12 \pm 1.39 \mathrm{bc}$ & $3.11 \pm 1.37 \mathrm{bc}$ & $6.08 \pm 1.60^{\mathrm{bc}}$ & $3.12 \pm 1.12^{\mathrm{bc}}$ & $6.29 \pm 1.41^{c}$ & $3.48 \pm 1.08^{c}$ \\
\hline CF5 & $6.28 \pm 2.03^{b}$ & $3.40 \pm 1.85^{b c}$ & $6.16 \pm 1.91^{b c}$ & $3.21 \pm 1.04 \mathrm{bc}$ & $5.72 \pm 1.77 \mathrm{~b}$ & $2.73 \pm 1.76^{\mathrm{b}}$ & $5.96 \pm 1.40^{\mathrm{bc}}$ & $3.12 \pm 1.05^{b c}$ & $5.32 \pm 1.68^{\mathrm{cd}}$ & $2.48 \pm 1.56^{\mathrm{cd}}$ & $5.22 \pm 1.19 \mathrm{~d}$ & $2.40 \pm 1.38^{\mathrm{d}}$ \\
\hline CF6 & $5.28 \pm 1.97 \mathrm{c}$ & $2.40 \pm 1.83^{\mathrm{d}}$ & $5.44 \pm 2.00^{c}$ & $2.60 \pm 1.68^{c}$ & $4.56 \pm 1.89 \mathrm{c}$ & $1.73 \pm 1.52^{\mathrm{c}}$ & $5.52 \pm 1.81^{c}$ & $2.56 \pm 1.73^{c}$ & $4.88 \pm 1.81^{\mathrm{d}}$ & $2.04 \pm 1.65^{\mathrm{d}}$ & $4.96 \pm 1.72^{\mathrm{d}}$ & $2.00 \pm 1.49 \mathrm{~d}$ \\
\hline \multicolumn{13}{|c|}{ Under Refrigeration } \\
\hline WF1 & $7.16 \pm 0.80^{\mathrm{a}}$ & $5.96 \pm 0.68^{b}$ & $6.64 \pm 0.95^{b}$ & $6.52 \pm 0.51^{b}$ & $6.44 \pm 1.45^{b}$ & $5.76 \pm 1.16^{\mathrm{b}}$ & $6.60 \pm 0.76^{b}$ & $5.72 \pm 1.72^{b}$ & $6.80 \pm 0.91^{b}$ & $6.36 \pm 1.49 \mathrm{~b}$ & $7.24 \pm 0.59 \mathrm{~b}$ & $6.56 \pm 1.00^{b}$ \\
\hline $\mathrm{CF} 2$ & $7.88 \pm 0.83^{a}$ & $7.00 \pm 0.70^{a}$ & $7.92 \pm 1.19 a$ & $7.36 \pm 0.81^{\mathrm{a}}$ & $7.68 \pm 1.31^{a}$ & $7.16 \pm 1.34^{a}$ & $7.40 \pm 1.41^{\mathrm{a}}$ & $6.96 \pm 1.49 \mathrm{a}$ & $7.96 \pm 0.98^{a}$ & $7.32 \pm 0.80^{\mathrm{a}}$ & $8.40 \pm 0.64^{a}$ & $8.20 \pm 0.96^{a}$ \\
\hline CF4 & $6.24 \pm 1.05^{b}$ & $5.56 \pm 0.58^{\mathrm{bc}}$ & $6.36 \pm 1.58^{b}$ & $5.80 \pm 0.96^{c}$ & $5.88 \pm 1.27 \mathrm{~b}$ & $5.36 \pm 1.11^{b}$ & $6.00 \pm 1.26^{b c}$ & $5.48 \pm 1.53^{b c}$ & $6.12 \pm 1.39 \mathrm{bc}$ & $5.76 \pm 0.78^{b}$ & $6.52 \pm 0.82^{c}$ & $6.16 \pm 1.34^{b}$ \\
\hline CF5 & $6.08 \pm 1.80^{b}$ & $5.32 \pm 1.11^{\mathrm{cd}}$ & $6.12 \pm 1.76^{b c}$ & $5.36 \pm 1.08^{c}$ & $4.92 \pm 1.99 \mathrm{c}$ & $4.56 \pm 1.12^{c}$ & $5.80 \pm 1.26^{c}$ & $5.24 \pm 1.83^{b c}$ & $5.44 \pm 1.33^{\mathrm{cd}}$ & $4.92 \pm 1.38^{c}$ & $5.40 \pm 1.32^{\mathrm{d}}$ & $5.20 \pm 0.82^{c}$ \\
\hline CF6 & $5.04 \pm 1.77 \mathrm{c}$ & $4.96 \pm 0.68^{d}$ & $5.44 \pm 2.00^{c}$ & $4.76 \pm 1.20^{\mathrm{d}}$ & $4.40 \pm 1.80^{c}$ & $4.20 \pm 0.50^{c}$ & $5.52 \pm 1.81^{c}$ & $4.64 \pm 1.68^{c}$ & $5.04 \pm 1.65^{\mathrm{d}}$ & $4.56 \pm 1.04^{c}$ & $4.92 \pm 1.68^{\mathrm{d}}$ & $4.56 \pm 1.04^{\mathrm{d}}$ \\
\hline
\end{tabular}

Legend: WF1 $=100 \%$ Wheat flour, CF2 = 20\% Pumpkin seed flour, CF4 $=40 \%$ Pumpkin seed flour, CF5 = 50\% Pumpkin seed flour, CF6 = 60\% Pumpkin seed flour. Values are given as mean \pm SD. Within columns, values followed by the same alphabets are not significantly different but those followed by different alphabets are significantly different $\mathrm{p}<0.05$.

Table 2 Physical properties of cakes prepared from wheat and pumpkin blends

\begin{tabular}{llll}
\hline Samples & Weight $\mathbf{( g )}$ & Volume $\left(\mathbf{c m}^{3}\right)$ & Specific volume $\left(\mathbf{c m}^{3} / \mathbf{g}\right)$ \\
\hline WF1 & $34.95 \pm 0.27^{\mathrm{d}}$ & $92.03 \pm 0.17^{\mathrm{d}}$ & $2.63 \pm 0.03^{\mathrm{ab}}$ \\
CF2 & $35.09 \pm 0.18^{\mathrm{d}}$ & $96.61 \pm 0.07^{\mathrm{a}}$ & $2.75 \pm 0.14^{\mathrm{a}}$ \\
CF4 & $36.18 \pm 0.19^{\mathrm{c}}$ & $94.88 \pm 0.17^{\mathrm{b}}$ & $2.62 \pm 0.12^{\mathrm{ab}}$ \\
CF5 & $37.33 \pm 0.27^{\mathrm{b}}$ & $93.59 \pm 0.76^{\mathrm{c}}$ & $2.51 \pm 0.12^{\mathrm{bc}}$ \\
CF6 & $39.16 \pm 0.02^{\mathrm{a}}$ & $91.89 \pm 0.17^{\mathrm{d}}$ & $2.35 \pm 0.04^{\mathrm{c}}$
\end{tabular}

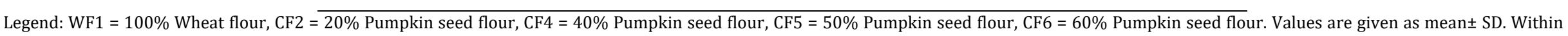
columns, values followed by the same alphabets are not significantly different but those followed by different alphabets are significantly different $\mathrm{p}<0.05$. 
Table 3 Peroxide values of cakes

\begin{tabular}{llllll}
\hline \multirow{2}{*}{ Sample } & \multicolumn{5}{c}{ Peroxide Value (meq/kg) } \\
& WF1 & CF2 & CF4 & CF5 & CF6 \\
\hline Cake & $5.23 \pm 0.02^{\mathrm{a}}$ & $4.92 \pm 0.04^{\mathrm{b}}$ & $4.61 \pm 0.01^{\mathrm{c}}$ & $4.44 \pm 0.02^{\mathrm{d}}$ & $4.23 \pm 0.03^{\mathrm{e}}$ \\
\hline
\end{tabular}

Legend: WF1 = 100\% Wheat flour, CF2 = 20\% Pumpkin seed flour, CF4 = 40\% Pumpkin seed flour, CF5 = 50\% Pumpkin seed flour, CF $6=60 \%$ Pumpkin seed flour. Values are given as mean \pm SD. Within rows, values followed by the same alphabets are not significantly different but those followed by different alphabets are significantly different $\mathrm{p}<0.05$.

\subsection{Microbiological analysis of cakes}

The microbial qualities of baked cakes at first and fourth days under ambient and refrigeration conditions are shown in Table 4. Bacterial and fungal counts (CFU/g) of baked cakes at both storage days and conditions ranged from $1.40 \times 10^{2} \pm 0.58$ to $2.99 \times 10^{3} \pm 1.00$ and $2.50 \times 10^{1} \pm 1.00$ to $2.40 \times 10^{2} \pm 2.08$ respectively. WF1 cake recorded the highest bacterial and fungal counts (CFU/g) for both storage days $\left(1.89 \times 10^{2} \pm 1.15 \& 1.88 \times 10^{2} \pm 2.00-\right.$ day $1 / 2.99 \times 10^{3} \pm 1.00$ \& $2.99 \times 10^{2} \pm 2.08$ - day 4$)$ and $\left(3.07 \times 10^{1} \pm 0.58 \& 3.03 \times 10^{1} \pm 1.52-\right.$ day $1 / 2.40 \times 10^{2} \pm 2.08 \& 9.67 \times 10^{1} \pm 1.53-$ day 4$)$, while CF6 recorded the least bacterial and fungal counts (CFU/g) for both storage days $\left(1.40 \times 10^{2} \pm 0.58 \& 1.42 \times 10^{2} \pm 2.52-\right.$ day $1 / 2.50 \times 10^{3} \pm 0.58 \& 2.30 \times 10^{2} \pm 4.04$ - day 4) and $\left(2.50 \times 10^{1} \pm 1.53 \& 2.50 \times 10^{1} \pm 1.00-\right.$ day $1 / 1.97 \times 10^{2} \pm 2.08 \&$ $3.80 \times 10^{1} \pm 1.73$ - day 4) under ambient and refrigeration conditions respectively. All values of microbial counts obtained when compared were statistically significant $(\mathrm{p}<0.05)$.

Table 4 Microbiological results of cakes prepared from wheat and pumpkin blends at different storage days and conditions.

\begin{tabular}{lllll}
\hline Samples & Bacteria (CFU/g) & & Fungi (CFU/g) & Day 4 \\
& Day 1 & Day 4 & Day 1 & \\
\hline Under Ambient & & & & $2.40 \times 10^{2} \pm 2.08^{\mathrm{a}}$ \\
\hline WF1 & $1.89 \times 10^{2} \pm 1.15^{\mathrm{a}}$ & $2.99 \times 10^{3} \pm 1.00^{\mathrm{a}}$ & $3.07 \times 10^{1} \pm 0.58^{\mathrm{a}}$ & $2.24 \times 10^{2} \pm 0.58^{\mathrm{b}}$ \\
CF2 & $1.75 \times 10^{2} \pm 0.58^{\mathrm{b}}$ & $2.84 \times 10^{3} \pm 1.15^{\mathrm{b}}$ & $2.80 \times 10^{1} \pm 1.00^{\mathrm{b}}$ & $2.21 \times 10^{2} \pm 2.00^{\mathrm{c}}$ \\
CF4 & $1.63 \times 10^{2} \pm 0.58^{\mathrm{c}}$ & $2.70 \times 10^{3} \pm 0.58^{\mathrm{c}}$ & $2.70 \times 10^{1} \pm 2.08^{\mathrm{bc}}$ & $2.08 \times 10^{2} \pm 1.00^{\mathrm{d}}$ \\
CF5 & $1.52 \times 10^{2} \pm 1.00^{\mathrm{d}}$ & $2.60 \times 10^{3} \pm 1.15^{\mathrm{d}}$ & $2.60 \times 10^{1} \pm 0.58^{\mathrm{bc}}$ & $1.97 \times 10^{2} \pm 2.08^{\mathrm{e}}$ \\
CF6 & $1.40 \times 10^{2} \pm 0.58^{\mathrm{e}}$ & $2.50 \times 10^{3} \pm 0.58^{\mathrm{e}}$ & $2.50 \times 10^{1} \pm 1.53^{\mathrm{c}}$ & \\
\hline Under Refrigeration & & & & $9.67 \times 10^{1} \pm 1.53^{\mathrm{a}}$ \\
\hline WF1 & $1.88 \times 10^{2} \pm 2.00^{\mathrm{a}}$ & $2.99 \times 10^{2} \pm 2.08^{\mathrm{a}}$ & $3.03 \times 10^{1 \pm} 1.52^{\mathrm{a}}$ & $7.43 \times 10^{1} \pm 1.53^{\mathrm{b}}$ \\
CF2 & $1.71 \times 10^{2} \pm 1.53^{\mathrm{b}}$ & $2.69 \times 10^{2} \pm 3.51^{\mathrm{b}}$ & $2.77 \times 10^{1} \pm 0.58^{\mathrm{ab}}$ & $6.20 \times 10^{1} \pm 2.00^{\mathrm{c}}$ \\
CF4 & $1.59 \times 10^{2} \pm 4.16^{\mathrm{c}}$ & $2.52 \times 10^{2} \pm 2.64^{\mathrm{c}}$ & $2.72 \times 10^{1} \pm 2.52^{\mathrm{b}}$ & $5.40 \times 10^{1} \pm 4.58^{\mathrm{d}}$ \\
CF5 & $1.49 \times 10^{2} \pm 2.00^{\mathrm{d}}$ & $2.40 \times 10^{2} \pm 3.05^{\mathrm{d}}$ & $2.63 \times 10^{1} \pm 1.53^{\mathrm{b}}$ & $3.80 \times 10^{1} \pm 1.73^{\mathrm{e}}$
\end{tabular}

Legend: WF1 = 100\% Wheat flour, CF2 = 20\% Pumpkin seed flour, CF4 = 40\% Pumpkin seed flour, CF5 = 50\% Pumpkin seed flour, CF6 = 60\% Pumpkin seed flour. Values are given as mean \pm SD. Within columns, values followed by the same alphabets are not significantly different but those followed by different alphabets are significantly different $\mathrm{p}<0.05$.

\section{Discussion}

\subsection{Sensory evaluation}

The highest score for all sensory parameters was obtained by CF2 blend and was found to be higher than control. The overall acceptability score of CF2 blend was significant $(\mathrm{p}<0.05)$ and higher than that of control and other three blends. Thus, indicating that cake supplemented with pumpkin seed flour at 20\% was better accepted than control (WF1) or any other blends. The obtained sensory result in this study is in agreement with the report of [2] during a work with 
cake supplemented with raw pumpkin seed flour involving four samples viz-a-viz one control and three test samples of different supplemented levels (10\%, 20\% and 30\%) and the overall acceptability score of T2 (20\% pumpkin) treatment in that research was higher than that of control and other two treatments. Thus, indicating that the cake supplemented with raw pumpkin seed flour at $20 \%$ level was better accepted than cake prepared with refined wheat flour. The sensory scores of day 1 were better and higher than that of day 4.

Consequently, sensory scores of cake samples kept under refrigeration were better and higher than that stored under ambient conditions. Notwithstanding, a general observation indicted pumpkin flour with an after-bitter taste in substitution percentages above 20 in the blended cakes, which intensified as storage days prolonged, hence the poor recorded scores in taste parameter (Table 1). The poor sensory scores at day 4 especially for samples stored under ambient conditions could also point towards spoilage of the cake. This is an indication of deterioration of physical, chemical and organoleptic properties of stored cake owing to microbial activities, which eventually causes spoilage of the cake. Hence, with the poor overall acceptability scores, there is need for preservatives and better storage conditions in order to extend the shelf life of the stored cake beyond 4 days.

Also, the addition of pumpkin seed flour affected the appearance, color, taste, texture, flavour and overall acceptability of the cakes. [26] reported that the different results in sensory attributes of pumpkin blended cakes may be due to the color and stronger flavor of pumpkin powder. [27] clarified that adding pumpkin powder to the cake enhanced the flavor of the cake. [28] stated that significant difference in sensory attributes exists between $10 \%$ and $15 \%$ pumpkin powder bread. [29] reported that the sensory characteristics of spongy cake processed using 5\%, 10\% and 15\% of pumpkin meal were acceptable to most members regarding to taste, odor, texture, color, appearance and overall acceptability. Also, [30] during the evaluation of physico-chemical properties of biscuits supplemented with pumpkin seeds to fight malnutrition in children of Pakistan reported that substitution treatment with $15 \%$ pumpkin seed flour scored highest (8.0) for maximum overall acceptability and an increasing trend in all sensory attributes among various treatments when compared with control.

\subsection{Physical properties}

As the blending ratio of PSF into WF1 increased, higher was the weight of the baked cakes and lower was the volume and specific volumes of the baked cakes. Although with CF2, there was a sharp increase of volume and specific volume, higher than that obtained with WF1, which later decreased with substitution of WF1 with higher ratios of PSF. This substitution of WF1 with increasing ratios of PSF resulted in significant increase in weight and decrease in volume and specific volume of baked cakes $(p<0.05)$.

Cake weights significantly $(\mathrm{p}<0.05)$ increased with increasing ratio of PSF (Table 2). In a similar report, [28] illustrated that increasing levels of pumpkin flour in bread manufacture $(0-15 \%)$ significantly increased the weight of loaf among samples and attributed this increase in weight to the pumpkin fiber content.

With increasing pumpkin flour ratios, volume and specific volumes of cakes decreased significantly ( $\mathrm{p}<0.05)$. According to [28], reducing the amount of wheat flour in the bread formulation caused less gluten matrix, resulting in bread with lower specific volume compared to the control. Also, it was stated that substitution of more than $10 \%$ pumpkin flour resulted in lower loaf volume of bread as compared with the control. A similar result to the assertion by [28], was recorded in this study in Table 2 with CF2. The less gluten matrix in pumpkin flour might cause a lower volume and specific volume of cake. Also, the decreased cakes volume and specific volume recorded in Table 2 among blends could be due to lower gas retention, causing less expansion of the product which is attributable to lower peak viscosity of flour [31]. Weights and volumes of baked products have been reported to be dependent on bulk density of the flour blends used [32]. The results obtained in the study are in agreement with the reports of [28; 32; 33].

\subsection{Peroxide value}

WF1 cake which was the control had the highest peroxide value when compared with the blended cakes. Conclusively, substitution of WF1 with different ratios of PSF during cake making resulted in significant $(p<0.05)$ decrease in peroxide values among blended cakes. As the blending ratio of PSF into WF1 increased, lower was the peroxide value of blended cakes. Hence, the substitution of WF1 with increasing levels of PSF resulted in significant $(p<0.05)$ decrease in peroxide values among blended cakes as shown in Table 3.

Peroxide values obtained in the blended cakes were retrogressive with increasing level of additions of PSF into WF1. Peroxide values of the blended cakes decreased as the level of PSF substitution increased. The decrease in peroxide values among the blended cakes may be attributed to high oil absorption capacity of wheat flour resulting from high starch content during baking [31]. 
Results of peroxide values obtained in this study were statistically significant $(p<0.05)$ and correlated with the assertions of [2]. According to [34] more peroxide value is harmful for shelf life of products. From the results obtained, blended cakes had a decreased peroxide values among the various baked cakes, which implies that substitution of WF1 with increasing levels of PSF during baking reduces the chances of rancidity and increases the shelf life of products.

\subsection{Microbiological studies}

There were significant differences $(\mathrm{p}<0.05)$ among various samples when compared along storage days. With the obtained high microbial counts recorded at day 4 especially during ambient storage condition, coupled with deteriorated sensory results obtained at same day 4 , there are indications of poor storage-quality condition of the cake leading to spoilage.

It was observed that WFI had higher bacterial and fungal counts at both day 1 and day 4 than the blends. Cakes stored under refrigeration had lower microbial counts compared to those stored under ambient conditions. The chilling of the refrigerator affected adversely the replication of microbial cells. This gave rise to reduced growth rate and counts observed among samples stored under refrigeration over those stored under ambient conditions. This confirms the assertion of [35] that most food spoilage microbes fall into the mesophilic group. Also observed during the study, was the correlation between moisture content, blending ratios and microbial counts [31]. As the moisture content decreased, lower were the recorded microbial counts. Also, as the blending ratio increased, lower were the recorded microbial counts. The former could be as result of the low moisture content of PSF over WF1, while the later could be attributed to high oil content of pumpkin seed flour (PSF) over wheat flour (WF1) as was observed by [31]. The results obtained in this study are in agreement with the works of [2] and [36].

Oil is an inhibitory substance that limits growth of aerobic microorganisms. It functions by sealing up the air pores through which air could flow in to support growth of aerobic microorganisms, thereby creating an unconducive environment that is devoid of oxygen (anaerobic). Oil on the other hand, could be used in preserving food and other edible items because of its negative tendencies in supporting microbial growth especially the aerobes [35].

The low moisture content of PSF over WF1 was another factor pointing towards the low microbial counts recorded in the blends. Both moisture content and microbial counts are directly proportional as the lower the moisture content, the lower was the microbial counts. According to [37], the preservation of foods by drying is a direct consequence of removal or binding of moisture, without which microorganisms do not grow. Moisture content could also be described in terms of water activity $\left(\mathrm{a}_{\mathrm{w}}\right)$ which is referred to as water requirements of microorganisms in the environment. This concept is related to relative humidity $(\mathrm{RH})$ as shown: $\mathrm{RH}=100 \times \mathrm{a}_{\mathrm{w}}$. Water activity plays a role with moisture content in the growth of microorganisms, as it is the available water for microbial growth.

\section{Conclusion}

The ravaging consequences of malnutrition among infants and children; preservation of vegetable and fruits as an excellent way to curb post- harvest losses which have been a major challenges in sub-sahara African countries; and utilization of underutilized agricultural products have resulted in the production of products with improved nutritional contents that could bridge the nutritional requirements lacking among infants and children. From the recorded results, $20 \%$ supplementation of pumpkin seed flour into wheat flour (CF2) produced cakes that had the most acceptable sensory, physical and microbiological qualities when compared with control and other levels of blends. Inclusion of pumpkin seed flour into baking processes enhances the organoleptic characteristics, shelf life properties and nutritional potentials of the baked cakes. Therefore, there is need for inclusion of pumpkin seed flour (PSF) into wheat flour (WF1) in order to improve the nutrient content, quality and acceptability potentials of our baked products.

\section{Compliance with ethical standards}

\section{Acknowledgments}

The authors are grateful to everyone who has contributed in one way or the other to the success of this feat.

\section{Disclosure of conflict of interest}

No conflict of interest. 


\section{References}

[1] Caili FU, Huan SH and Quanhong LI. (2006). A review on pharmacological activities and utilization technologies of pumpkin. Plant Foods for Human Nutrition, 61, 70-80.

[2] Manpreet K. (2017). Development and nutritional evaluation of pumpkin seed (Cucurbita moschata) supplemented products. Unpublished M.Sc. Thesis, Department of Food and Nutrition, College of Home Science, Punjab Agricultural University, Ludhiana-141004, 1-89.

[3] Al-Khalifa AS. (1996). Physicochemical characteristics, fatty acid composition and lipoxygenase activity of crude pumpkin and melon seed oils. Journal of Agriculture and Food Chemistry, 44, 964-66.

[4] Marcone FM, Kakuda Y and Yada RY. (1997). Salt-soluble seed globulins of various dicotyledonous plants: isolation, purification and characterization. Food Chemistry, 62, 27-47.

[5] Idouraine A, Khan MJ, Kohlhepp EA, Weber CW, Warid WA and Malrinez-Tollez JI. (1996). Nutrient constituents from light lines of naked squash (Cucurbita pepo L.). Journal of Agriculture and Food Chemistry, 44(3), 721-724.

[6] Younis YMH, Ghirmy S and Al-Shihry SS. (2000). African Cucurbita pepo L: Properties of seed and variability in fatty acid composition of seed oil. Phytochemistry, 54, 71-75.

[7] Sicilia T, Niemeyer HB, Honig DM and Metzler M. (2003). Identification and stereochemical characterization of lignans in flaxseed and pumpkin seeds. Journal of Agricultural and Food Chemistry, 51, 1181-1188.

[8] Mukesh Y, Shalini J, Radha T, Prasad GBKS and Hariom Y. (2010). Medicinal and biological potential of pumpkin: an updated review. Nutrition Research Reviews, 23, 184-190.

[9] Quanhong L, Ze T and Tongyi C. (2003). Study on the hypoglycemic action of pumpkin extract in diabetic rats. ActaNutrimentaSinica, 25, 34-36.

[10] Wang HX and Ng TB. (2003). Isolation of cucurmoschin: A novel antifungal peptide abundant in arginine, glutamate and glycine residues from black pumpkin seeds. Peptides, 24, 969-72.

[11] Nkosi CZ, Opoku AR and Terblanche SE. (2006). Antioxidative effects of pumpkin seed (Cucurbitapepo) protein isolate in CCL4 induced liver injury in low protein fed rats. PhytotherapyReserach, 20, 935-40.

[12] Dhiman. (2009). African Cucurbitapepo. Properties of seed and variability in fatty acid composition of seed oil. Journal of Phytochemistry, 54(1),71-75.

[13] Ptitchkina NM, Novokreschonova LV, Piskunova GV and Morris ER. (1998). Large enhancements in loaf volume and organoleptic acceptability of wheat bread by small additions of pumpkin powder: Possible role of acetylated pectin in stabilizing gas-cell structure. Food Hydrocolloids, 12, 333-337.

[14] Gajigo 0 and Lukoma A. (2011). Infrastructure and agricultural productivity in Africa: Market brief, AFDB (African Development Fund).

[15] Ike CC and Emeka-Ike PC. (2016). Bacteriological Quality of Processed African Oil Bean Seed (Pentaclethramacrophylla) sold in Umulolo and Ihube Communities in Okigwe, Imo State, Nigeria. International Journal of Scientific Engineering and Applied Science (IJSEAS), 2(5), 126-136.

[16] Patel S. (2013). Pumpkin (Cucurbitasp) seeds as neutraceutic: A review on status quo and scopes. Mediterrenian Journal of Nutrition and Metabolism, 6, 183-89.

[17] Maneju H, Udobi CE and Ndife J. (2011).Effect of added brewers dry grain on the physico-chemical, microbial and sensory quality of wheat bread. American Journal of Food Nutrition, 1(1), 39- 43.

[18] Ndife J and Abbo E. (2009). Functional foods: prospects and challenges in Nigeria. Journal of Science Technology, 1(5), 1 - 6.

[19] Zoulias VE, Oreopoulou V and Kounalaki E. (2002). Effect of fat and sugar replacement on cookies properties. Journal of the Science of Food and Agriculture, 82, 1637-1644.

[20] Giami SY and Barber LI. (2004). Utilization of protein concentrates from ungerminated and germinated fluted pumpkin (Telfoririaoccidentalis Hook) seeds in cookies formulations. Journal of the Science of Food and Agriculture, 84, 1901-1907.

[21] Kiin-Kabari DB and Banigo EB. (2015). Quality characteristics of cakes prepared from wheat and unripe plantain flour blends enriched with bambara groundnut protein concentrate. European Journal of Food Science and Technology, 3(3), 1-10. 
[22] Onwuka GI. (2018). Food Analysis and Instrumentation: Theory and Practice. 2ndEdition. Naphthali Prints. Surulere, Lagos Nigeria, 146-161.

[23] Cappucino GJR and Sherman B. (2010). Microbiology: A Laboratory Manual, 9 $9^{\text {th }}$ Edition. The Benjamin Publishing Company. California.

[24] Boone DR, Castenholz RW, Garrity GM, Brenner DJ, Krieg NR and Staley JR (Eds.). (2005). Bergey's Manual of Systematic Bacteriology. Second Edition. New York: SpringerVerlag.

[25] Kidd S, Halliday C, Alexiou H and Ellis D. (2016). Description of Medical Fungi. $3^{\text {rd }}$ Edition. Newstlye Printing. Adelaide, South Australia 5031, Australia, 23-170.

[26] Jesmin AM, Ruhul AM and Chandra MS. (2016). Effect of pumpkin powder on physico-chemical properties of cake. International Resources Journal of Biological Sciences, 5(4), 1-5.

[27] Roongruangsri W and Bronlund JE. (2016). Effect of air-drying temperature on physico-chemical, powder properties and sorption characteristics of pumpkin powders. International Food Resources Journal, 23(3), 962972.

[28] See EF, Wan Nadiah WA and Noor Aziah AA. (2007). Physico-chemical and sensory evaluation of breads supplemented with pumpkin flour. ASEAN Food Journal, 14, 123-130.

[29] Ali ShW (2015). Nutrition with pumpkin (Cucrbitapepo) cake as lowering cholesterol in rats. Middle East Journal of Applied Sciences, 5(1), 10-19.

[30] Kanwal S, Raza S, Naseem K, Amjad M, Naseem B and Gillani M. (2015). Development, physico-chemical and sensory properties of biscuits supplemented with pumpkin seeds to combat malnutrition in Pakistan. Pakistan Journal of Agricultural Resources, 28,400-405.

[31] Emeka-Ike PC. (2020). Potentials of wheat and pumpkin (cucurbitapepo) seed composite flours in cake making. Unpublished M.Sc. Thesis, Department of Food and Technology, Faculty of Engineering, Imo State University, Owerri, 1-124.

[32] Chinma CE, Ingbian EK and Akpapunam MA. (2007). Processing and acceptability of fried cassava balls ("Akaraakpu") supplemented with melon and soyabean flour. Journal of Food Processing and Preservation, 31, 143-156.

[33] Wongsagonsup R, Kittisuban P, Yaowalak A and Suphantharika M. (2015). Physical and sensory qualities of composite wheat-pumpkin flour bread with addition of hydrocolloids. International Food Research Journal, 22(2), 745-752.

[34] Adeel R, Sohail A and Masud T. (2014). Characterization and antibacterial study of pumpkin seed oil. Life Science Leaflets, 49,53-64.

[35] Ike CC, Emeka-Ike PC, Nwokorie CC and Anochie CC. (2015). Microbiological quality evaluation of locally prepared snacks sold in Aba metropolis, Abia State, Nigeria. International Journal of Scientific Engineering and Applied Science (IJSEAS), 1(7), 46-59.

[36] Chaudhari SN, PalveSB, Choudhari KR, Pawar DH and Gaikwad SS. (2017). Microbial analysis of ragi cake base stored at room temperature without added chemical preservative. International Journal of Current Microbiology and Applied Sciences, 6(12), 3519-3525.

[37] Jay MJ, Loessner MJ and Golden DA. (2005). Modern Food Microbiology, Seventh Edition. Springer Publishers, USA, 39-60. 